\title{
TANK: THE PROGRESS OF A MONSTROUS WAR MACHINE
}

\section{Patrick Wright}

Faber and Faber

London

2001, pages 499

ISBN: 0571207456

The tank is viewed as the concrete manifestation of speed, mobility, allround protection and firepower on the modern battlefield. Since its first operational deployment, it has received detailed and in-depth attention in terms of design, armament and upgrades, as well as strategy and tactics, including the evolution of armour strategy, doctrine and tactics on the battlefield. The tank redesigned battle space and has become a permanent fixture of conventional warfare over the past century. ${ }^{1}$

For generations, this tool of war has been part of the social discourse, nationalist fervour, the projection of power politics, the spreading of 'democracy' and the subject of intense discussion. Of the many books written on the tank, few have touched on its broader social meaning and role in history. ${ }^{2}$ Putting it differently, few have philosophised the tank. Wright's work looks at the tank from an entirely different and refreshing angle. ${ }^{3}$ While the centenary of the start of the First World War is celebrated in 2014, it is worth reflecting on the tank that made its name at Cambrai and the Somme - breaking through static battle space - and thus became a tool of war with immense destructive potential as demonstrated in the Second World War, wars in the Middle East and elsewhere.

To mention but a few questions touched upon in Wright's outstanding piece of work: What has the tank to do with mysticism, with Eastern religions or occultism? What links are there with Xenophon and King Cyrus? What has the tank to do with recollections about the Anglo-Boer War, the Veda and yoga? Or, for that matter, with the Old Testament with its tales of brutality, vengeance and redemption and hero worship? Or with Jimi Hendrix, Punch Magazine, Waterloo and Cubism? Or even with people forcefully resettled in New York in 1991? Or with Picasso, HG

Scientia Militaria, South African Journal of Military Studies, Vol 42, Nr 2, 2014, pp. 188-194. doi : $10.5787 / 42-2-1100$
Wells, Monet and Sorolla y Bastida, the École Beaux-Arts in Paris or stained-glass windows in Christian places of worship, gender debates or the notion of memorialisation, remembrance or collective consciousness, nationalism and 
the deconstruction of nationalisms? ${ }^{4}$ What at all has this tool of war to do with political scientists, sociologists, anthropologists, (military) historians, theologians, even artists and philosophers?

This review touches on some of these ideas and their implications. It is nigh impossible to touch on all the themes reflected upon in Wright's work, but some will be mentioned.

Wright predictably shares a line or two on the (pre-) history of the tank and its design. In 1335, Guido da Vigevano suggested a 'battle car'. He was followed a hundred odd years later by Leonardo da Vinci. The visions of Da Vigevano and Da Vinci saw little practical outcome. In 1838 John George and his son, who lived in Cornwall, wrote a petition to the House of Commons proposing a design of a 'modern steam chariot'. They asked what would have happened at the Battle of Waterloo if their enemy had possessed a piece of heavily protected mobile firepower. Such a creation would have allowed Napoleon's cavalry to change the battle and the fate of nations. ${ }^{5}$

Wright's most important contributions are the links made with social phenomena such as art, religion, ideology (i.e. nationalism and patriotism), social (resistance) movements and social media. Wright points out the social value of the tank in the perpetuation of nationalist-religious propaganda. He provides telling historical examples such as stained-glass windows in Britain with images of weaponry - howitzers, Zeppelin airships and the tank, every image inscribed with a Biblical quotation. ${ }^{6}$ If the tank was born in the church of mechanisation, it was certainly welcome in the Church of the Lord, and was presented as redeemer of national loss, protector, symbol of eventual victory and the fervour of the nation reinvigorated. ${ }^{7}$ In short, the tank became part of the trinity of religion, nationalist fervour and the right to fight a 'just war' against an undesired people or a declared enemy. The tank can be seen as a concrete tool of power and a signifier of offensive military and political strategies justified by religion, or what can be called a "civil religion". 8

Churches and tanks and tanks in churches are not where a nation's flirtation with tanks ends. Wright investigates the relationship between art and the tank in war, and provides stunning examples of art in support of the tank and art as subversion, if not social resistance to the tank as tool of war/symbol of power. As the land battleship crawled into action in 1916 and 1917 during the Battle of the Somme and at Cambrai and elsewhere, human imagination played its part. "The tank broke over the static geography of trench warfare with all the force of a freakish sea crashing overland." A Behemoth from the deep, the tank represented "transformative geography in war time and space; a great destroyer breaking through the stasis of the now ... [effecting] a deep structural change in the social world". 10 Referring to Hilda Doolittle's work, Wright suggests, "like those taut Imagist 
poems, the tank was a [design] of sudden conversion that broke up habituated perspectives to outline new possibilities". 11

In the 1930s, Gertrude Stein claimed that the Great War itself was Cubist (and) a decentred activity with no beginning or end. ${ }^{12}$ Stephen Kern suggested that Stein's Cubist War entailed "the war's fragmentation of time into endless flux of life in trenches ... a cataclysmic differentiation ... the 'Cubist' provided a decisive breakthrough in the geography of modern battle". ${ }^{13}$ Marinetti insisted, that "art should offer a machine-like assault on forces of the unknown". ${ }^{14}$ HG Wells refers to the British Futurist and Cubist CRW Nevinson as "clinching the appearance of Nature with a discreet application of Cubism". ${ }^{15}$ For C Lewis Hinds, Nevinson, the enfant terrible of WW1 art, was a "fighting artist who rampaged like a tank through all modern movements ... Out of Cubism he has brought to birth a curious geometrical formulae (sic) ... admirably suited to his vision of this scientific mechanical war." 16 Nevinson himself was sceptical: "(M)an made the machine in his own image. The machine retaliated by re-making man in its own image." 17

Art in killing, art as camouflage and camouflage as art are addressed by Wright. While some artists talked about Cubism, others were concerned with practice. Solomon J Solomon was one. He became a war artist/artisan/analyst and specialised in tank camouflage thus extending Sun Tzu's argument on deception in battle, keeping in mind material geography.

Wright gives attention to what he prefers to call throughout the book the tank philosophers. These parts make for interesting reading. The tank philosophers in their thinking went against the traditionalist and conventional grain. They gaily seemed to play havoc with hallowed tradition thereby gaining little immediate popularity. In turn, they were described as "men with fantastic ideas" and the "happy thought brigade". ${ }^{18}$ Examples of tank philosophers mentioned are JFC Fuller, Mikhail Tukhachevsky, Vladimir Kiriakovich Triandafillov, Heinz Guderian, Basil Liddell Hart and Erwin Rommel. The majority of tank philosophers had difficulty dealing with the mindset of the traditional military where hierarchy and cultural controls mark institutions, and such top-down, uncritical and unreflected-uponthinking permeates all customs and values. Bring in ideology, the notion of a total institution, and groupthink and more complications arise (to be fair, not only the military, but also civil bureaucracy and politicians suffer from frozen habits, mental myopia and - frequently - groupthink).

The tank philosophers found themselves deeply at odds with the typical military mindset. Swinton describes the War Office as a place marked by "rigid nonreceptivity and [lazy] omni-science". ${ }^{19}$ Swinton was fairly diplomatic in his description, but was still removed from his post. If Swinton was diplomatic, others were less so. Captain Evan Edward Charteris, a tanker, referred to one of the HQ commanders as "... a disciplinarian of the old school who believes everything can 
be done by order ... rigid and quite uneducated outside soldiering ... the kind of colonel that thinks that martial law is a remedy for strikes, shooting a cure for discontent, and bayonets a cure for social ills". ${ }^{20}$ Tankers at Bermicourt, the tank training section, referred to the "stupidity and lack of imagination of the General Head Quarters". High Command (HC) offered the "absolute negation of a guiding mind". Colonel Hugh Ellis told his superior, that "fighting the Germans is a joke compared with fighting the British $\mathrm{HC} "{ }^{21}$ Fuller suggested that developments at the time were "impeded everywhere by convention, vested interests and the bovine stupidity of the red tabbed hierarchy $\ldots$ backed up by dim witted politicians ... [who] could chew on a cud of habit but never in a million years digest or convert it into new forms". 22

Nonetheless, the tank philosophers pursued their ideals despite adversity and mockery, until the tank found its way into battle. Later the German General Von Zwehl would say, "It was not the genius of Marshall Foch that defeated us, but 'General Tank'." ${ }^{23}$ Erich Maria Remarque in All quiet on the western front sums it up saying, "From a mockery tanks have become a terrible weapon." 24

Wright touches on globalisation, cyber developments and what has become known as trans-humanity in a so-called 'postmodern world' (some Western ideologues would call it the era of hyper-globalisation). Space and time imploded under globalisation. Contemporary tank philosophers, with the help of high technology, are re-configuring the tank to put man at the centre of the tank. Israel Tal, a contemporary Israeli tank philosopher and practitioner, redesigned the Mercava tank to bring man back to the centre of the tank. No more man in the tank, but man now at the centre of the tank. Wright shares some impressions from a visit to the US Army Armour Centre at Fort Knox, which makes for fascinating reading even if the ideas are thought to be absurd. The US tank of the future "will be a landship sailing over a frictionless ocean of virtual turf" says the Advanced Warfighting Working Group associated with the US Army. Soldiers (or rather operators/agents/players) for the job are easy to find as "the kids who have done a lot of DVD games have exactly the right kind of hand-eye coordination ... Nintendo has done great things for this generation," argues the Chief of Staff of the US Armour School, Colonel Lenze in rather cynical terms. ${ }^{25}$ For some reason, the honourable colonel neglected to say that the hand-eye coordination needed in the cyber age is aimed at killing and maiming people and the ultimate maintenance of power.

Wright provides interesting examples of the subversion of the symbolism of the tank. One is Wang Weilin, the lonely Chinese student who stood in the way of a line of tanks at Tiananmen Square. The image was quickly picked up by international media. "Tankman" was born. Observers "fell upon the image of Tiananmen converting it into a sign of the spiritual and political condition of our 
times". ${ }^{26}$ For Italian literary theorist Giorgio Agamben, Tiananmen heralded the beginning of a new kind of "non-state" which goes beyond mere protest movements. ${ }^{27}$ Some consensus was established that this incident was a sign of "the unsubdued subject standing out against the ever more total power of the state". ${ }^{28}$

The Prague incident of April 1991 is mentioned. One morning citizens of Prague woke up to see their tank memorial painted in bright pink. A student in applied arts in Prague and his colleagues did so. Uproar broke out, not only in Prague, but over the whole Eastern bloc. The Academy of Fine Arts in Prague defended the action. The tank was repainted, but some members of parliament "restored" it to its "pink order". The tank became politicised and proved that different generations in Czechoslovakia had entirely clashing interpretations of the tank as symbol in the history of the country and its people. ${ }^{29}$

In 1983, one of Francesc Torres' multimedia creations reflected on the tank. The exhibition was entitled Tough Limo. The striking link between the limousine (as a symbol of the upper class) and the tank (as an aggressive tool to uphold privilege) was highlighted. The 'tough limo' is the cold, shielded selective protection of a selfappointed community, namely the haves, and is thus the carrier of estrangement, alienation and (proto-) womb for social conflict. Torres suggests that the tank reflects a reptilian complex (like a society where privileges are coldly restricted to the few haves) and "it is a territorial weapon, it intimidates by appearance ...",30 Anselmus Kiefer portrays the tank as an "enemy of art and spirituality, it emblems abstract power and aggressive forgetfulness". 31

Wright provides another interesting example where the design and purpose of the tank were inverted. In the same year that the USA invaded Iraq, one of the major shanty towns in New York was destroyed by the city council. New York elected its first black mayor, David Dinkins, and he promised progressive policies, financial reform and support for the poor. The budget defaulted and the mayor flunked a major test of leadership. ${ }^{32}$ Wright describes the desperate situation around the homeless, a situation usually associated with so-called "Third World" societies. Political leadership failing on promises made, frequently turn authoritarian. Dinkins and his advisors decided on a clean-up of shanties. The USA version of Robert Mugabe's Operation Clean Up in Harare, Zimbabwe started on 15 October 1991 in New York. Bulldozers under armed guard went in to wipe away the shanties (and presumably all social ills). ${ }^{33}$

Krzysztof Wodiczko, an artist, designed and developed the Poliscar as a critical comment on the undermining of promises of social justice and the subversion of democracy in New York. The contraption, part mobile home, part art, part social statement, included images from Kafka, Goya, Aldo Rossini and Tatlin's Tower harking back to designs of Da Vinci. ${ }^{34}$ The Poliscar was first seen at Tompkins Square Park, reminiscent of the Jimi Hendrix Experience, the Grateful 
Dead and the Fugs concerts, but also "skirmishes of full scale street battles with punks and anarchists in solidarity with squatters". 35 The Poliscar redefined public space and the safety of the squatter: it was mobile house, mobile shop and a political statement. It was symbolic of a civic guerrilla strategy for survival against authoritarian and elite practices aimed at emasculating the homeless and deepening the gap between rich and poor. The Poliscar symbolised a demilitarised option against an increasing atmosphere of authoritarianism and non-care in the USA, and is remembered as a symbol of mobile resistance, redefining urban geography and a new dynamic demography for societies under the onslaught of the rich; thus, a symbol of both subversion and social resistance, perhaps even a revolution of some sort.

Wright makes a wide traverse in the story of the tank. The tank philosophers brought about change, if not progressive interruption in battle space, but did not push through to other deeply embedded questions. They got themselves caught up in the whirlwind of war despite their open-mindedness. It seems that there remains what Shi Ming and Weijia call "the crude consciousness, in need of many levels of training until a certain kind of qualitative transformation takes place" before peace becomes a human praxis. ${ }^{36}$

Can such qualitative transformation ever be achieved? Given the suction of liberal capitalism and the powerful addiction of the military-industrial complex, is escape possible? Reading Wright and reflecting on his well-referenced research, including the exhaustive use of archives and interviews, it is too early to say. Until then, and with the sociological imagination that $\mathrm{C}$ Wright Mills talks about, one can foresee numerous intended and unintended consequences unfolding. Wright's work is not only a definite read but should also be prescribed material for students in political science, strategy, military history and the engineering sciences.

Ian Liebenberg, Centre for Military Studies, Stellenbosch University

\section{Endnotes}

${ }^{1}$ Wright, P. Tank: The progress of a monstrous war machine. London: Faber and Faber, 2001, 23.

${ }^{2}$ Hundreds of books were written on the tank; far too numerous to mention here. Apart from Wright's work one publication worth consulting is: Smithers, A. J. A New Excalibur: The Development of the tank 1909-1939. Glasgow: Grafton Books, 1988.

${ }^{3}$ Wright, P. Tank: The progress of a monstrous war machine. London: Faber and Faber, 2001, 23.

4 There is not time, nor space to look at the role of religion, nationalism, the (authoritarian) national state and the military in detail here, although Wright 
touches poignantly on these concepts. An interesting collection of essays on the nation state, nationalism and the military is to found in: International Commission of Military History (ICMH). Nationalstaat, Nationalismus und Militär. XXXII ICMH Congress held in Potsdam. Potsdam: Ehlert and Heinemann. 2006.

5 Ibid., p. 23.

${ }^{6}$ Ibid., p. 111.

${ }^{7}$ Ibid., p. 115.

8 For a definition of civil religion, see Liebenberg, I. Ideologie in Konflik. Emmerentia: Taurus Uitgewers, 38, 40. See also Ferrante, J. 2011. Seeing Sociology. Singapore: Wadsworth, 446-448.

${ }^{9}$ Wright, P. Tank: The progress of a monstrous war machine. London: Faber and Faber, 2001, 54.

${ }^{10}$ Ibid., p. 55.

${ }^{11}$ Ibid., p. 55.

12 Ibid., p. 55.

${ }^{13}$ Ibid., p. 55.

${ }^{14}$ Ibid., p. 57.

15 Ibid., p. 59.

${ }^{16}$ Ibid., p. 59.

${ }^{17}$ Ibid., p. 59.

${ }^{18}$ Ibid., p. 27.

${ }^{19}$ Ibid., p. 27.

${ }^{20}$ Ibid., p. 62.

${ }^{21}$ Ibid., p. 68.

${ }^{22}$ Ibid., p. 145.

23 Ibid., p. 146.

${ }^{24}$ Ibid., p. 146.

${ }^{25}$ Ibid., p. 413.

${ }^{26}$ Ibid., p. 10.

${ }^{27}$ Ibid., p. 10.

${ }^{28}$ Ibid., p. 10.

${ }^{29}$ Ibid., p. 385.

${ }^{30}$ Ibid., p. 377.

${ }^{31}$ Ibid., p. 378.

32 Ibid., p. 392.

33 Ibid., p. 402.

${ }^{34}$ Ibid., p. 394.

${ }^{35}$ Ibid., p. 395.

${ }^{36}$ Ming, S \& Weijia, S. Mind over matter: Higher martial arts. Berkley, CA: Frog, 1994, 101-102 